\title{
Where There Is No Quantity Surveyor: The Dilemma Of Civil/Heavy Engineering Construction Project Delivery.
}

\author{
O. OSUBOR (FNIQS, RQS)
}

\begin{abstract}
In any construction where value for money is the watchword, the quantity surveyor, cost expert and economist of the construction industry are invaluable. But in Nigeria, the relevance/value and services of the quantity surveyor are not maximized especially in civil and heavy engineering projects. It is therefore hard to find consultant quantity surveyors in roads and bridges, petrochemical, oil and gas, rail and other heavy engineering projects. This is not acceptable in global best practice. Some argue that the quantity surveyors competence is limited to building and housing construction and has no competence to cost and manage engineering projects. This paper advocates that the quantity surveyor both by training and experience in construction and engineering technology has the competence to give and enable clients of all forms of construction project delivery to get value for their money. A comparative study approach using ten substructure projects was tabulated. It revealed that in projects where qualified professional quantity surveyor was not involved, clients and developers could not obtain value for money. Structured questionnaire was also administered to practitioners/stakeholders in the construction industry. Data collected was tested using z-score tool at $5 \%$ significance level. Respondents significantly agree that quantity surveying services are very relevant to successful delivery of Heavy Engineering construction projects. External threats from other profession usurping the duties of the quantity surveyor, lack of publicity of the quantity surveyor, ignorance of global best practices are some factors that contribute to the situation. An earlier proposal by The Federal Ministry of Works to create a separate department for quantity surveying in ministries requires a positive consideration.
\end{abstract}

Keywords: Value for money, Civil, Heavy Engineering, construction projects, Project delivery

\section{Introduction}

A popular best seller and village health care handbook titled 'Where there is no Doctor' by David Werner (2011), gives probable guide/prescriptions to help victims of health challenges and in emergency cases where a trained medical doctor is not readily available or within reach. But the title of this paper 'Where there is no Quantity Surveyor' does not envisage nor prescribe an option or alternative of what should be done where the services of a professional quantity surveyor is not involved or engaged on a building and engineering construction project rather the paper aims to warn on the dangers of embarking on a construction project of any type or scale without first consulting and engaging the services of an independent consultant professional quantity surveyor. Jesus Christ could not imagine undertaking any building and civil engineering construction project without first engaging the services of a professional quantity surveyor and therefore queried (Luke 14:28 "who of you suppose to build a tower and does not first sit down and count the cost"?). Quantity Surveying is a unique profession and an indispensable part of the development process in the construction industry. The construction industry accounts for between 6\% - 9\% of GDP in most countries but in Nigeria it is estimated at about 3\% - 6\% (Isa, Jimoh \& Achuenu 2013) and contribution valued at about N5.7bn.(Lolade, 2015). The construction industry is invariably a significant part of the process of growing a developing economy especially in the area of job creation, boosting the economy and contributing to GDP growth and national development. Cartlidge (2009) noted that the process of economic development can be enhanced and accelerated by the quantity surveyor. The core objective of construction industry is to deliver projects within scheduled time frame, reasonable cost and good quality (Best and Valence 1998). This requires input from all professionals in the industry. The various professions have certification and regulatory bodies established by law in Nigeria and their scope of services properly defined. However, there is little or no records of the involvement of quantity surveyors in civil/heavy engineering projects in the country as well there is no record of any capital project that has delivered on schedule and cost. The aim of this paper is to evaluate the place and relevance of the quantity surveyor in capital project delivery. The paper examines some factors why quantity surveyors are not involved in civil and heavy engineering projects and outlines the dangers of not engaging the quantity surveyor.For example, Ogunsemi (2015) reported of a study completed by the International Programme in the Project Management of Engineering and Construction (IMEC) in 2000. Miller \& Lessard (2000) revealed that $18 \%$ of 60 large engineering and construction projects with an average capital value of $\$ 1$ bn undertaken between 1980 and 
2000, incurred extensive cost overruns. Merrow, McDonnell \& Arguden (1988) studied 47 mega projects in the construction environment and found that only 4 were on budget with an average cost overrun of $88 \%$.

Among some of the professionals involved in the construction project delivery, there is the notion that the quantity surveyor's competence is limited to buildings and housing construction, alleging that the quantity surveyor cannot offer expertise in civil, oil and gas, telecommunication and other heavy engineering capital projects. However, a critical look at the curricula of training of the quantity surveyor in Polytechnics and Universities, the recent introduction of Building and Engineering Standard Method of Measurement (BESMM4), QS Academy, and Quantity Surveyors Registration Board of Nigeria (QSRBN) curriculum review of Polytechnic and University review in March 2016, which has been adopted by regulatory bodies of universities and polytechnics among other developments in the profession render such opinions unsustainable.

Questions that are relevant in this study are:

i) Is the quantity surveyor competent to cost and manage civil and heavy engineering contracts?

ii) What are the implications of not involving quantity surveyor in civil/heavy engineering construction projects?

Hypothesis

Hypothesis was formulated to test the authenticity of respondent's opinions: $\mathrm{H}_{\mathrm{o}} 1$ Respondents do not significantly agree that quantity surveyors have competence to cost manage civil/heavy engineering projects.

$\mathrm{H}_{0} 2$ Non involvement of quantity surveyors does not affect successful project delivery of civil/heavy engineering projectsThe quantity surveying profession is dynamic. Mc Donagh (1991) has observed that the nature of change in market demand and in the supporting technologies has brought about evolutional changes in the nature of the Quantity Surveying profession over the last 20 years. There is no reason to believe that change will not be a feature of the future as well. The unique knowledge base and unique skills in the profession is fundamental to matching the Quantity Surveying services to market demand. The Quantity Surveying technologies, techniques and relative importance have all increased considerably. The general principles that apply in building also apply to any other related field of engineering construction. The design and construction stages and contracting depends on contractual arrangement as in building, whether design contract and build or design and build or tendering process all apply. In global best practices, the duty of the quantity surveyor on a project is to enable the developer get value for money, hence, the absence or non involvement imply loss and this becomes an issue in a quest for national development. Characteristically, construction projects are unique, complex and time consuming as no two projects are ever alike. Although the Nigerian Institute of Quantity Surveyors (NIQS) is relatively young in Nigeria compared to the older professions like Nigerian Institute of surveyors 1934, Nigerian Society of Engineers (NSE) 1958 and the Nigerian Institute of Architects (NIA) 1960, the contribution and involvement of the services of the quantity surveying profession has been very appreciable. In construction and development projects where the watchword is value for money, the quantity surveyor must be involved from the inception. The quantity surveyor may not necessarily be a design expert in construction but would necessarily require acquiring basic knowledge required to function in those respective fields (to enable them provide the relevant cost advice). The quantity surveyor is the financial expert in all matters of cost of construction projects where value for money is required NIQS (2008) right from the inception of a project to its substantial conclusion. No other professional is more competent to provide cost expert advice in construction than the quantity surveyor). Absence of the quantity surveyor at the design stage will result in over design, uneconomic design and wrong tendering and contractual arrangement and non involvement of the quantity surveyor at post contract stage will lead to cost overrun, time over run, variation, poor cost control low profit margin or loss, delay, abandonment, collapse etc. There are two major parties in a construction contract - the client/developer and the contractor. While the client aims to get value for his money the contractor aims to make reasonable profit from the contract. According to Best \& De Valence (1998) and Takim \& Akinloye (2002), construction project development involves numerous parties, various processes, phases and stages of work and a great deal of inputs from both the public and private sectors with the major aim of bringing the project to a successful conclusion "construction process is commonly expressed in terms of establishing equilibrium between the three principal concerns of time, cost and quality" and noted that "clients would like to construct a facility of the highest quality, at minimum cost and in the shortest possible time", even though the criteria conflict, just as Pilcher (1992) stated that "few companies can survive unless they are successful. To be successful, they must first of all obtain the work necessary to keep the organization more or less fully occupied; secondly, they must carry out the work they have obtained in such a way that they make profit" The opinion in the public domain is that cost is the most significant and most important criteria of the three parameters the other parameters of time and quality being a function and effect of cost. Both client and contractor need the professional quantity surveyor to achieve their respective goals. While the client appoints a quantity surveyor to represent and protect his interest, the contractor also employs a quantity surveyor to offer services to control cost of executing work to enable him maximize profit on his contract and agree any issues with the independent quantity surveyor. The consultant quantity surveyor is invaluable in civil and heavy engineering projects. and 
it's the focus of this paper..The experience of The Apostolic Church of Nigeria: The World's largest Church in Nigeria (Eyoboka \& Latona (2011), should serve as a lesson for clients. During the commissioning of the project that took 25 years to construct, in an interview with the press, the national president of the church claimed that at the end of the project, they do not know how much they have spent and hope to engage accountants to determine the total cost of a completed project that had lasted 25 years. What is the impact of the involvement of a professional quantity surveyor in any project?

\subsection{The History of Quantity Surveying}

The quantity surveying professions relevance has not been understood and appreciated, and in some cases, other professions ignorantly or by coercion and impunity would want to delve into his duties. This has prompted the Nigerian Institute of Quantity Surveyors both at the national and State levels to embark on career enlightenment in secondary schools, workshops and conferences etc to promote awareness and public enlightenment of the profession.Before the $19^{\text {th }}$ century, according to Grafton (1966), the quantity and cost of construction could not be assessed before construction work commenced on site. Builders executed work and on completion would engage measurers to collate the cost of materials, labour, overhead and profit and negotiate with the client and architects (Seeley, 1996). This process was plagued with disputes, loss of time and goodwill between the client and architect on the one hand and the builder and his measurers on the other hand (Jagboro, 1989). The introduction of the main contracting system in the $19^{\text {th }}$ century according to Seeley (1996) implied price competition before construction commenced on site. This led to the development of pre-measuring/taking off quantities from designs and assembling them into a bill of quantities (BOQ) for the purpose of tendering and contractual arrangements. Eke (2007), noted that the Quantity Surveyor was traditionally charged with the responsibility of measuring and valuing building works in the $19^{\text {th }}$ century, based on the concept of complete design of the building before construction and then paying the various craftsmen for their individual work quantities on completion. Most people see Quantity Surveying as a rather technically based profession for preparing Bills of Quantities, providing a kind of backup supporting the activities of the far more important skills applied within the design and management of construction. The Quantity Surveying profession has grown beyond that to providing value management oriented services in areas of optimum Bidding efficiency methods and procurement that are basic to the entire design and construction process regarding decisions made in relation to design and function, economic front and funding mechanisms appropriate to particular projects (McDonagh, 1991).Talking about building cost, total building cost depends on much more than mere construction cost; it includes related cost such as design fees, interest and holding charges, legal costs, cost of repairs and maintenance, occupancy and operating costs. Ikpo and Olusola (2000) pointed out "that the initial cost of construction represents only a small part of the cost of a building over its lifetime. Even the cost of design is so small when considered against the life cycle cost of a building that it is almost insignificant - somewhere between 0.1 and $1 \%$ ". It is in the early stages of the design and documentation process that many of the most important decisions that determine the ultimate value of final product are made. However for many clients, initial/capital cost is a dominant factor.Dennis (1997), sees no point in designing a project that will cost N5000 $/ \mathrm{m}^{2}$ when the client can only afford $\mathrm{N} 2000 / \mathrm{m}^{2}$ and can only get N1800/m $\mathrm{m}^{2}$ in return. Singh and Singh (2004), posited that cost can be seen in the total amount spent on a project but more importantly on the value of what it is spent. This is the focal point of feasibility studies

\subsection{Justification for the study}

The success of projects is measured by the parameters of time, cost and quality. However, it is common knowledge in Nigeria that most civil/heavy engineering construction projects have not performed well on each of these parameters. There is probably no other sector that has such significant implication on the everyday life of humans than the construction industry. The industry accounts for a significant portion of the world and Nigerian Gross Domestic Product, providing job creation opportunities and boosting economy of nations. Civil/heavy engineering projects here refer to single construction contract projects that run into billion and trillions of naira. In the USA they are termed Mega projects. Examples are roads and bridges, rails, tunnels, sewage, refinery, oil and gas etc. As cost is the distinguishing factor in capital projects, it becomes an issue that the cost expert in construction is left out or his professional role taken over by others not competent in those areas (quackery). Especially those most civil/heavy engineering projects are undertaken by government using taxpayer's money that requires accountability.It is a common notion especially in Nigeria that engineers can design and cost and manage heavy engineering projects using Bill of Engineering Measurement and Evaluation (BEME). Over the years, there are no records of any civil/heavy engineering project that has been successfully delivered hence the need for change of strategy and operation. Time over run, poor quality and maintenance cost outweighing initial cost at short period and cost overrun are characteristics of many. This is negative to national development and there is need to remedy the situation using the professionals competent and equipped for the task. However, a major challenge or problem facing the quantity surveying profession in Nigeria is that of 
obscurity. The quantity surveying profession is relatively young in Nigeria compared to earlier professions. A little boy on the street in any urban town can tell who a medical doctor, Architect, Engineer and lawyer is and what they do. The same cannot be said of the Quantity Surveyor. The quantity surveying profession is both young and battling for recognition probably because his position and relevance has not been understood and appreciated. The quantity surveyor presently operates under the earlier professions and does not have a separate department in the ministries and departments charged with initiation, award and supervision of heavy engineering contracts and in some cases other professions usurp his duties (Esenwa, 2008). The Government being the largest employer of the services of the quantity surveyor at present time reflects the attitude of the Nigerian society. It is the habit of the government to approve projects and release warrants for capital grants allocation even without cash backups despite the provisions of the Public Procurement Act (2007).

\subsection{Value for Money}

The principle of value for money involves getting the best possible satisfaction from the services provided and requires that the overall benefits of the activity be weighed up and compared with the overall cost (Ogunsemi, 2015). The quantity surveyor is concerned with obtaining value for money. Value for money is not easy to define. What it means fluctuates with time and circumstances (Nisbet, 1991). For example, in the early 1800s it meant getting more reliable prices by restructuring the building industry. In the 1950s, it meant getting lower prices. In the 1980s, it meant getting faster completions. The purpose however remained the same. The perception of what value for money means and how it is achieved has changed over time and will go on changing, but the distinctive competence of the Quantity Surveyor remains the same while its methods have changed and will continue to do so to suit circumstances. Since construction project delivery is a team work, the quantity surveyor is not the only professional who ensures the client obtain value for money in all its ramifications, but the central position of total cost management and procurement strategies, the core competence of the quantity surveyor, gives the profession a unique role.For most people, value for money means constructing a facility at a cheap or minimum cost. Though noble, this may not necessarily be the case in every project as quality is a function of cost. Most Clients are only concerned with the initial cost of completing the project but may not take the maintenance and running cost into consideration and in only a few years the running cost will outweigh the initial cost and the facility becomes uneconomical. There is a philosophy and maxim in Singapore that 'good things are not cheap and cheap things are not good' and this corroborated by the philosophy of John Ruskin (1819-1900)' It not the cheaper things in life that we wish to possess, but expensive things that cost less. It is possible to execute and complete a facility and feel great without knowing that the same can be achieved at a less cost, less time and better quality. When is a client said to get value for money? In classical economics, the value of an item is related to its utility (Best \& Valence, 1998). When discussing value, there are other factors other than price/cost that have to be considered. Cost here refers to a measure of the value of a product in monetary terms and it is determined by the interplay of the forces of supply and demand and its relative to scarcity. Value can be described as the level of the degree of satisfaction attached to/derived from an asset or service. In Construction projects, value is often discussed in terms of the relationship between time, cost and quality. Every rational client will desire to construct a project/facility that perfectly balances the competing criteria of time, cost and quality. The aim is to maximize quality while minimizing cost and time. There must be a compromise between the three as they are always in conflict. The interdependency that exists between the three criteria is complex and requires careful analysis during design making procedures. But could higher quality and short termism live together? Queried Nisbet, Only where the value of the project when completed substantially exceeded the price of construction. Value for money now required the use of tendering and contract systems which would enable projects to be completed at a much earlier date maybe by overlapping design and construction, implying incomplete design at pre contract stage. The mentality of an average person is that they get value once a facility is constructed cheaply. . Cost reduction does not imply value. Initial cost plus operational/maintenance cost must be computed to enable determine if a client is to get value for money or whether a design or construction is economical.

\subsection{The Quantity Surveyors Role in Heavy Engineering Projects}

The stage and scope of the quantity surveyors involvement largely depend on the type of procurement, tendering process and contractual arrangement strategy and standard form of contract adopted for the project. In global best practices, it is the quantity surveyor that should carry out feasibility study, determine and inform on the initial cost of the project, advice on the best method of tendering and contractual arrangement that will suit the project and manage costs to contract close out. The core competencies of the quantity surveyor would provide accurate measurement, valuation (work executed/unexecuted items), verify quality/specifications and reduction of waste. Training and experience in quantity surveying can therefore be a valuable preparation for managerial responsibilities in other areas. The principles and methodologies of quantity surveying can apply equally to other industries with construction characteristics. The difference between such industries and construction lie in 
the nature of the technology, technical terms inherited and often pragmatic practices and institutional protectionism. These differences should not explain the absence of quantity surveying methods in industries other than construction (Nisbet, 1991). For most heavy engineering projects in Nigeria, Design and Build or Package Deal, Public Private Partnership, Negotiation, Concession, Build Operate and Transfer arrangements are common that even allows design to overlap construction in preference to the traditional methods. The quantity surveyors role will include cost economics and life cycle costing of designs, advice on tendering and contractual arrangement for the projects, value variations, control cost during contract execution, claims and final accounts preparation and contract close out.

Njoku (2014) attributed the high cost of procuring civil and heavy engineering projects in Nigeria to non utilization of the quantity surveyor who by training are equipped to give value for money on all construction projects from conceptualization through to the execution of such projects. The same reasons give rise to several uncompleted and abandoned projects in the country. This is manifest due to mismatch between the available funds and what the consultant has designed. The quantity surveyor is able to reduce cost overrun by drawing attention to implications of designs, specifications and choice or selection of alternative materials. It is common in Nigeria that the engineer designs a project and at the same time does the costing. The Bill of Engineering Measurement and Evaluation (BEME) being used by engineers is not internationally recognized. It is not a sound global best practice but rather impunity and a ploy to retain grip of the construction process. The recognition of the Nigerian Society of Engineer and non inclusion of the Nigerian Institute of Quantity Surveyors in the Council of Public Procurement Supervisory body of Public Bureau of Procurement (Public Procurement Act, 2007) is a case in point.

\subsection{METHOD OF DATA COLLECTION AND ANALYSIS}

For this study, four road construction projects, a 10,000 capacity Olympic size Stadium, an earth dam, and airport all in Delta state was chosen based on convenience and familiarity with the researcher. The researcher visited and had interviews with Two chief executives of construction companies, Two Permanent Secretaries, Two Directors (Highways) and Eight Engineers in the ministry of Works, Eleven Site Engineers on construction projects, four civil engineering lecturers, seven practicing quantity surveyors and six quantity surveying lecturers. The interview bothered on clients and engineers appreciation of the role of the quantity surveyor in civil and heavy engineering construction projects. Forty eight questionnaires were administered while forty two respondents returned the usable survey questionnaire showing a response rate of eighty eight percent. This formed the primary data for this study. The data obtained was tabulated and tested using the z-score tool at 5\% level of significance. Secondary data was obtained from the substructure of ten projects familiar to the researcher, (ongoing or abandoned). The substructure element was selected because it is the first major construction activities on site to enable assess projects progress and also as a provisional element that require re measurement on completion. The initial and final cost of five projects in which quantity surveyor was involved was compared with five projects where the quantity surveyor was not involved.

Table $2.1 \quad$ Projects without quantity surveyors

\begin{tabular}{|c|c|c|c|c|}
\hline Project & $\begin{array}{l}\text { Initial } \\
\text { Estimate }(\mathrm{N})\end{array}$ & Actual/ Final cost (N) & $\begin{array}{l}\text { Difference \% } \quad(+ \\
\text { or -) }\end{array}$ & Remarks \\
\hline A & $5,732,000$ & $6,943,500$ & $21.1 \%$ increase & $\begin{array}{l}\text { Initial estimate by clients } \\
\text { estimation }\end{array}$ \\
\hline B & Not available & Not available & Pending completion & $\begin{array}{l}\text { No Qs involved, project } \\
\text { abandoned }\end{array}$ \\
\hline $\mathrm{C}$ & Not available & $26,214,000$ & $\begin{array}{l}\text { Estimated at } 18 \% \\
\text { cost overrun }\end{array}$ & $\begin{array}{l}\text { Re measured and re awarded, } \\
\text { Based on analysis of a similar } \\
\text { project }\end{array}$ \\
\hline $\mathrm{D}$ & $2,154,300$ & $\begin{array}{l}\text { Not available } \\
\text { (work still in progress) }\end{array}$ & $?$ & $\begin{array}{l}\text { QS engaged only for pre contract } \\
\text { documentation }\end{array}$ \\
\hline $\mathrm{E}$ & Not available & Not available & Pending completion & $\begin{array}{l}\text { Cannot be confirmed, project } \\
\text { abandoned }\end{array}$ \\
\hline
\end{tabular}

Source: From field study 2008 - 2015

Table 2.2 Projects involving the professional quantity surveyor

\begin{tabular}{lllllll}
\hline Project & Initial cost $(\mathrm{N})$ & $\begin{array}{l}\text { Actual/Final } \\
(\mathrm{N})\end{array}$ & $\begin{array}{l}\text { cost } \\
\text { Differen } \\
\text { ce }\end{array}$ & Remarks \\
\hline A & $62,664,505$ & 52,034104 & $17 \%$ & $\begin{array}{l}\text { Savings arising from Substructure re } \\
\text { measured }\end{array}$ \\
B & $1,774,205$ & $1,486,535$ & $16.2 \%$ & Savings arising from Change order \\
C & $2,250,515$ & $2,020,170$ & $10.2 \%$ & &
\end{tabular}




\begin{tabular}{lllll}
$\mathrm{D}$ & $6,385,640$ & $5,285,895$ & $17.2 \%$ & Savings obtained from unexecuted items \\
$\mathrm{E}$ & $4,538,800$ & $4,058,500$ & $10.6 \%$ & Savings arising from Substructure \\
\hline
\end{tabular}

Source: Substructure bill of quantities of projects 2010 - 2015

Table 2.3: Respondents' opinion on the competence of the quantity surveyors to cost and manage heavy engineering projects

\begin{tabular}{lllllcc}
\hline & $\begin{array}{l}\text { Strongly } \\
\text { Agree }\end{array}$ & Agree & Undecided & Disagree & $\begin{array}{l}\text { Strongly } \\
\text { Disagree }\end{array}$ & Total \\
\hline Chief Executives & - & 1 & - & 1 & - & 2 \\
Perm Secretaries & - & 1 & 1 & - & - & 2 \\
Directors (highways) & - & - & - & 2 & - & 2 \\
Engineers(MOW) & - & 3 & 1 & 4 & - & 8 \\
Site Engineers & 2 & 3 & 3 & 2 & 1 & 11 \\
Civil Engineering Lecturers & - & 3 & 1 & - & - & 4 \\
Quantity Surveyors & 5 & 2 & - & - & - & 7 \\
Qs Lecturers & - & 5 & - & 1 & - & 6 \\
Total & 7 & 18 & 3 & & & 42 \\
\hline
\end{tabular}

Testing hypothesis 1

$\mathrm{H}_{\mathrm{o}} 1$ Respondents do not significantly agree that quantity surveyors have competence to cost manage civil/heavy engineering projects.

$\mathrm{Z}_{\mathrm{cal}}=\frac{x-n p}{\sqrt{n p q}}$

$\mathrm{Z}_{\alpha / 2}=1.96$

i.e. $Z_{0.025}=1.96$

Decision: Since $Z$ calculated (1.23) is less than $Z$ critical (1.96), we do not reject the null hypothesis, but however, considering the opinion of 25 respondents that agree as against 16 in the negative, we can conclude that the opinion of respondents that quantity surveyors do not possess the competence to cost and manage heavy engineering projects in Nigeria is not very significant because the outcome of the poll must have been influenced by the imbalance in the structure and population sample selected for the survey which tilt in favour of 26 engineers to 13 quantity surveyor

$\mathrm{Z}_{\mathrm{cal}}=\frac{25-42 \times 0.5}{\sqrt{42 \times 0.5 \times 0.5}}=\frac{4.00}{3.24}=1.23$

s.Does the absence of the quantity surveyor justify why cost overrun, time overrun and poor quality work characterize heavy engineering projects.

Table 2.4: Respondents' opinions on the non involvement of quantity surveyor in civil and heavy engineering projects

\begin{tabular}{|c|c|c|c|c|c|c|}
\hline & $\begin{array}{l}\text { Strongly } \\
\text { Agree }\end{array}$ & Agree & Undecided & Disagree & $\begin{array}{l}\text { Strongly } \\
\text { Disagree }\end{array}$ & Total \\
\hline Chief Executives & 1 & - & 1 & - & - & 2 \\
\hline Perm Secretaries & - & 2 & - & - & - & 2 \\
\hline Directors & - & 1 & 1 & & - & 2 \\
\hline Engineers & 1 & 3 & 2 & 2 & - & 8 \\
\hline Site Engineers & 1 & 4 & 1 & 3 & 2 & 11 \\
\hline $\begin{array}{l}\text { Civil Engineering } \\
\text { Lecturers }\end{array}$ & - & 3 & - & 1 & - & 4 \\
\hline $\begin{array}{l}\text { Quantity } \\
\text { Surveyors }\end{array}$ & 3 & 3 & 1 & - & - & 7 \\
\hline Qs Lecturers & - & 6 & - & - & - & 6 \\
\hline Total & 6 & 22 & 6 & 6 & 2 & 42 \\
\hline
\end{tabular}

Testing hypothesis 2

$\mathrm{H}_{0} 2$ Non involvement of quantity surveyors does not affect successful project delivery of civil/heavy engineering projects

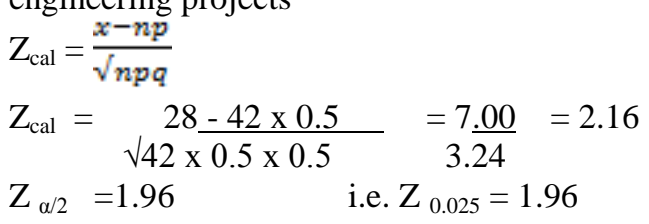




\section{DECISION:}

Since $\mathrm{Z}$ calculated (2.16) is greater than $\mathrm{Z}$ critical (1.96), we reject the null hypothesis and accept that non involvement of the quantity surveyor affect successful delivery of engineering projects. This is so glaring that despite the imbalance in the structure and population sample size of respondents in favour of engineers, respondents overwhelmingly agree that non involvement of quantity surveyors effect successful project delivery of civil and heavy engineering projects in Nigeria.

\subsection{Discussion}

In the five projects studied, where no quantity surveyor was involved, see Table 2.1, projects A and C recorded $21.10 \%$ and $18 \%$ increase respectively while for projects B, D and E, actual cost could not be determined due lack of cost documentation. It is doubtful that client could obtain value for money. The projects that did not involve the quantity surveyor cannot be used to predict probable cost of future projects when compared with projects in which quantity surveyor was involved. Conflicts, lack of supervision, cost and time overruns, poor quality control, waste are common features in such projects. In projects where the quantity surveyor was involved, see Table 2.2, they all recorded a savings in the substructure after re measurement. The savings range from $10.20 \%$ to $17 \%$. Factors such as the quantity surveyors professional competence, residency, cost control measures, reduction of waste significantly contributed to the successful delivery of the projects at the point of study.In response to the questionnaire (see Table 2.3), it reveals quantity surveyors generally have a very high opinion of their own performance while engineers/non- quantity surveyors have a lower opinion of that same performance but in key areas like carrying out feasibility studies, procurement, tender and contract documentation and evaluation, cost management and contract close out, quantity surveyors and non quantity surveyors views are in complete alignment. However, in some specific areas like budget estimate, delay analysis and claims assessment both views are markedly divergent. Respondents note with concern that in most heavy engineering projects in Nigeria, Concessionary, Design and Build, Build, Operate and Transfer, Public Private Partnership and other procurement options are largely adopted coupled with the influx of foreign experts providing/using foreign technologies, specifications, documentation and communication that are foreign to the Nigerian engineering practitioners. Also, lack of creation of a separate department for quantity surveying in ministries and all tiers of government as advocated by a former Minister for Works in 2003 is also a factor mitigating the involvement of the quantity surveyor in civil/heavy engineering construction projects as the government is the largest client of civil and heavy engineering contracts.

\subsection{Challenges}

Contractually, for a successful project delivery, feasibility study and budgeting involving the quantity surveyor should precede design, followed by tendering and contractual arrangement and contract before construction. However, circumstances like time, funding and risk allocation may warrant some variations to this process. The challenges that face successful project delivery of engineering projects also include

i) Lack of independence of consultant quantity surveyor

ii) Politics of corruption and impunity as practiced in Nigeria

iii) The engagement of quacks and unqualified persons acting as professional quantity surveyors

iv) Lack of proper planning and adequate time for pre contract planning/documentation

v) Level of technological development that necessitates most heavy engineering projects let to foreign experts whose operating system differ with the Nigerian environment.

\section{Conclusion}

All construction work is regulated by cost/money and value for money requires the effective management of construction costs. The contribution of the construction industry is significant to the economic and national development of any nation considering the huge capital allocated to infrastructure in annual budgets of tax payers money of government resources. Quantity surveying is therefore deeply involved in meeting the construction needs of the client, end user and national development at a price they can afford. Saving in cost, project time delivery, less conflict, providing records for predicting cost of future projects, reduce waste which is colossal in construction, and prevent project abandonment and collapse. The quantity surveyor by training, practice and experience has the competence more than any other professions in the construction industry to enable clients get value for money. With the current economic situation of recession facing the nation, the involvement of the quantity surveyor will enable clients obtain value for money. The curriculum for the training of the quantity surveyor is adequate to cost and manage civil and heavy engineering projects. The unique knowledge base and unique skills in the profession is fundamental to matching the Quantity Surveyors services to market demand. 


\section{Recommendation}

It is observed that Architects and Engineers have always dominated headship of positions and ministries where civil and heavy engineering construction contracts are initiated, awarded and processed without the involvement of professional consultant quantity surveyor and this has always frustrated successful project delivery and inability to obtain value for money. There is therefore need to revisit the proposal of a former minister for Works, 2003 to create a department of quantity surveying in the ministry of works. A proper delineation of the professional responsibilities of the various professions in the built environment becomes necessary and critical. The prompt implementation of the review of National Universities Commission (NUC)/National Board for Technical Education (NBTE) syllables to improve the Educational policy, professional content, widening application, profile and image of profession both internally and externally is apt. It is hoped that a review of the Public Procurement Act 2007 will also appreciate the role of the quantity surveyor. Adequate time should be allowed for planning and documentation for effective cost management of projects. There is need to create/establish a Directorate of Budget and Economic Planning to be headed by Quantity Surveyors in every level of government.

\section{References}

[1]. Best, R. \& Valence, G. (1998), Building in Value. Arnold Publishers, London.Eke, C. (2007), Quantity Surveying: A Reforming Cost Control Profession. Journal of theNigerian Institute of Quantity Surveyors. Vol. 55. No.2. pp3

[2]. Esenwa, F. O. Jnr. (2008). Global Perspectives on Quantity Surveying, Cost Engineering and Project Management. Paper delivered at Nigerian Institute of quantity Surveyors Conference.

[3]. Eyoboka, S. \& Latona, O. (2011), The World's Largest Church in Nigeria. Http://www.vanguardngr.com Accessed 6/12/2011

[4]. Grafton, P. W. (1966), Cost Planning. The Chartered Quantity Surveyor, May Dennis P, (1997), “The Architect and the Chartered Surveyor", Chartered Quantity Surveyor, July, Vol.7, pp - 477

[5]. Ikpo, I. I. \& Olusola, K. (2000), Life Cycle Costing of Residential Buildings: The role of Design. Journal of Construction Technology and Management, Vol.3, No.1, pp23-31

[6]. Isa, R. B., Jimoh, R. A., \& Achuenu E. (2013), An Overview of the Contribution of Construction Sector to Sustainable development in Nigeria. National Journal of Business Management. Vol. 1(1), pp 1-6, Nov.

[7]. Jagboro, G. O. (1989), Principles and Practice of Quantity Surveying. Fancy Publications, Ile-Ife.

[8]. Lolade, O. (2015). Construction Industry Contributed N5.7bn in GDP in 3 years: NBS reveals.. Accessed 12/2/2015.

[9]. McDonagh, N. (1991), 'Future Stock or Future Secured?'. Chartered Quantity Surveyor, June, pp10-14

[10]. Merrow, E. McDonnell, L. \& Arguden, R. (1988). 'Understanding the Outcome of Mega Projects: A qualitative analysis of very large civilian projects'. Rand Reports

[11]. Nigerian Institute of Quantity Surveyors, (2008). Quantity Surveying Career Guidance and Counseling Education Committee Pamphlet:

[12]. Nisbet, J. (1991), 'Identifying the Knowledge Base'. Chartered Quantity Surveyor, June, pp10-14

[13]. Njoku, J (2014), Quantity Surveyors Decry High Cost of Engineering Projects. Http://www.vanguardngr.com Accessed 23/12/2014

[14]. Ogunsemi, D. R. (2015), Value for Money in Construction Projects.: The quantity surveyors quest. Inaugural lecture series 71, pp 31

[15]. Pilcher, R. (1992), Principles of Construction Management: $3^{\text {rd }}$ Edition, McGraw Hill Book Co. Limited. UK.

[16]. Seeley, I. H. (1996). Building Economics. Sixth Edition, Palgrave Macmillan, London. Singh, G and Singh, J. (2004), Estimating, Costing and Valuation. $3^{\text {rd }}$ Edition, standard Publishers and Distributors, Delhi

[17]. Takim, R. \& Akinloye, A (2002), A Conceptual Model for Successful Project Performance. Paper presented at the Second International Post Graduate Research Conference in Built and Human Environment, University of Salford. $11^{\text {th }}-12^{\text {th }}$ April

[18]. Werner, D. (2011). Where there is no Doctor. Twelfth Edition, Hesperian health guides, USA. 